\title{
Polyploid evolution and Pleistocene glacial cycles: A case study from the alpine primrose Primula marginata (Primulaceae)
}

\author{
Gabriele Casazza ${ }^{1 *}$, Laura Granato ${ }^{1}$, Luigi Minuto ${ }^{1}$ and Elena Conti ${ }^{2}$
}

\begin{abstract}
Background: Recent studies highlighted the role of Pleistocene climatic cycles in polyploid speciation and of southern Alpine refugia as reservoirs of diversity during glacial maxima. The polyploid Primula marginata, endemic to the southwestern Alps, includes both hexaploid and dodecaploid cytotypes that show no ecological or morphological differences. We used flow cytometry to determine variation and geographic distribution of cytotypes within and between populations and analyses of chloroplast (cp) and nuclear ribosomal (nr) DNA sequences from the Internal Transcribed Spacer (ITS) region to infer the evolutionary history of the two cytotypes and the auto- vs. allopolyploid origin of dodecaploid populations.

Results: We did not detect any intermediate cytotypes or variation of ploidy levels within populations. Hexaploids occur in the western and dodecaploids in the eastern part of the distributional range, respectively. The cpDNA and nrDNA topologies are in conflict, for the former supports shared ancestry between P. marginata and P. latifolia, while the latter implies common origins between at least some ITS clones of $P$. marginata and $P$. allionii.

Conclusions: Our results suggest an initial episode of chloroplast capture involving ancestral lineages of P. latifolia and $P$. marginata, followed by polyploidization between $P$. marginata-like and $P$. allionii-like lineages in a southern refugium of the Maritime Alps. The higher proportion of ITS polymorphisms in dodecaploid than in hexaploid accessions of $P$. marginata and higher total nucleotide diversity of ITS clones in dodecaploid vs. hexaploid individuals sequences are congruent with the allopolyploid hypothesis of dodecaploid origin.
\end{abstract}

Keywords: Allopolyploidy, Flow cytometry, Non-adaptive processes, Phylogeny, Primula marginata, Alps, Refugia, Pleistocene, Climate change, Taxonomy

\section{Background}

Polyploid speciation, characterized by a heritable increase in the copy number of the nuclear genome, has played a key role in plant evolution [1-7]. Indeed, recent analyses estimated that all seed plants trace their origins to a few polyplodization events [1] and that $15 \%$ of speciation events involved polyplodization [8]. Occurring either between (i.e., allopolyploidization) or within the same species (i.e., autopolyploidization), polyploidization often involves hybridization between genetically differentiated populations, also in the latter case $[9,10]$. Polyploids can form repeatedly from different populations of

\footnotetext{
* Correspondence: gabriele.casazza@unige.it

'DISTAV, University of Genova, Corso Dogali 1M, I-16136 Genova, Italy

Full list of author information is available at the end of the article
}

the same progenitor species (i.e., polyphyletic origins), a pattern that further contributes to the increase of genetic variability typical of polyploids, as compared to relatives at lower ploidy levels [11,12]. Additionally, the higher genetic variability and the epigenetic alterations usually associated with polyploids have been invoked to explain their wider ecological tolerance and adaptive success [13-16].

The effects of Pleistocene glacial cycles on alpine and arctic regions presumably played a key role in promoting polyploid speciation. According to the secondary contact model $[17,18]$, glacial advancement during glacial maxima fragmented once continuous populations that then differentiated in isolation. Upon glacial retreat, these partially differentiated populations may have come into contact again, occasionally giving origin to hybrids that

\section{Biomed Central}


were then stabilized by polyploidization. The higher genetic variability and adaptive potential of the polyploids would have increased their ability to become established in newly available areas following glacial retreat, thus explaining the higher frequency of polyploids at higher altitudes and latitudes [19]. Molecular investigations have since provided evidence supporting speciation via secondary contact in several alpine/arctic species (e.g., [20-24]).

Polyploidization within the context of the Pleistocene glacial cycles has been proposed as the main evolutionary process driving the diversification of at least two sections in the alpine/arctic genus Primula [25]: Primula sect. Aleuritia [23,26-28] and Primula sect. Auricula [25,29-32]. The latter section includes $P$. marginata Curtis, endemic to the south-western Alps [25]. Populations at both the hexaploid $(2 n=6 x=62,66)$ and dodecaploid $(2 n=12 x=120-128)$ levels have been reported in P. marginata (Figure 1), the former occurring primarily in the western (i.e., from the Cottian to the southwestern Maritime Alps) and the latter in the eastern part of its range (i.e., from the south-eastern Maritime and Ligurian Alps to the Apennines [31,33,34]). Recently, new disjoint populations of undetermined ploidy level were described in the northern Apennines [35,36].

Both allo- and auto-polyploid hypotheses have been suggested to explain the origin of the $12 \mathrm{x}$ populations of P. marginata. Favarger [33] proposed that the dodecaploid populations derived from hybridization between hexaploid individuals of $P$. marginata and $P$. latifolia Lapeyr., probably owing to the frequent co-occurrence of the two species. On the contrary, Kress [34] favored an autopolyploid origin, owing to the absence of any morphological and ecological differences distinguishing the two ploidy races. In nature, $P$. marginata is known to hybridize with $P$. latifolia [30] and $P$. allionii Loisel. [25], both co-occurring species of sect. Auricula (Figure 1). In cultivation, $P$. marginata has also occasionally formed hybrids with $P$. hirsuta All., another co-occurring species of sect. Auricula, but natural hybrids between these two species are unknown [25].

The present study is aimed at clarifying the geographic distribution of $P$. marginata cytotypes and their evolutionary history by determining the ploidy levels of multiple populations across the entire species range and investigating their phylogenetic relationships with increased infra-specific sampling. More specifically, we are asking the following questions: 1 ) What is the variation of ploidy levels in $P$. marginata? Are there any intermediate cytotypes? 2) Do hexaploid and dodecaploid populations of $P$. marginata occupy distinct areas of the species range, as suggested by published cytological investigations [31,34]? 3) Do hexaploid and dodecaploid populations form reciprocally monophyletic groups? 4) Are the dodecaploid populations of allopolyploid or autopolyploid origin, as proposed by Favarger

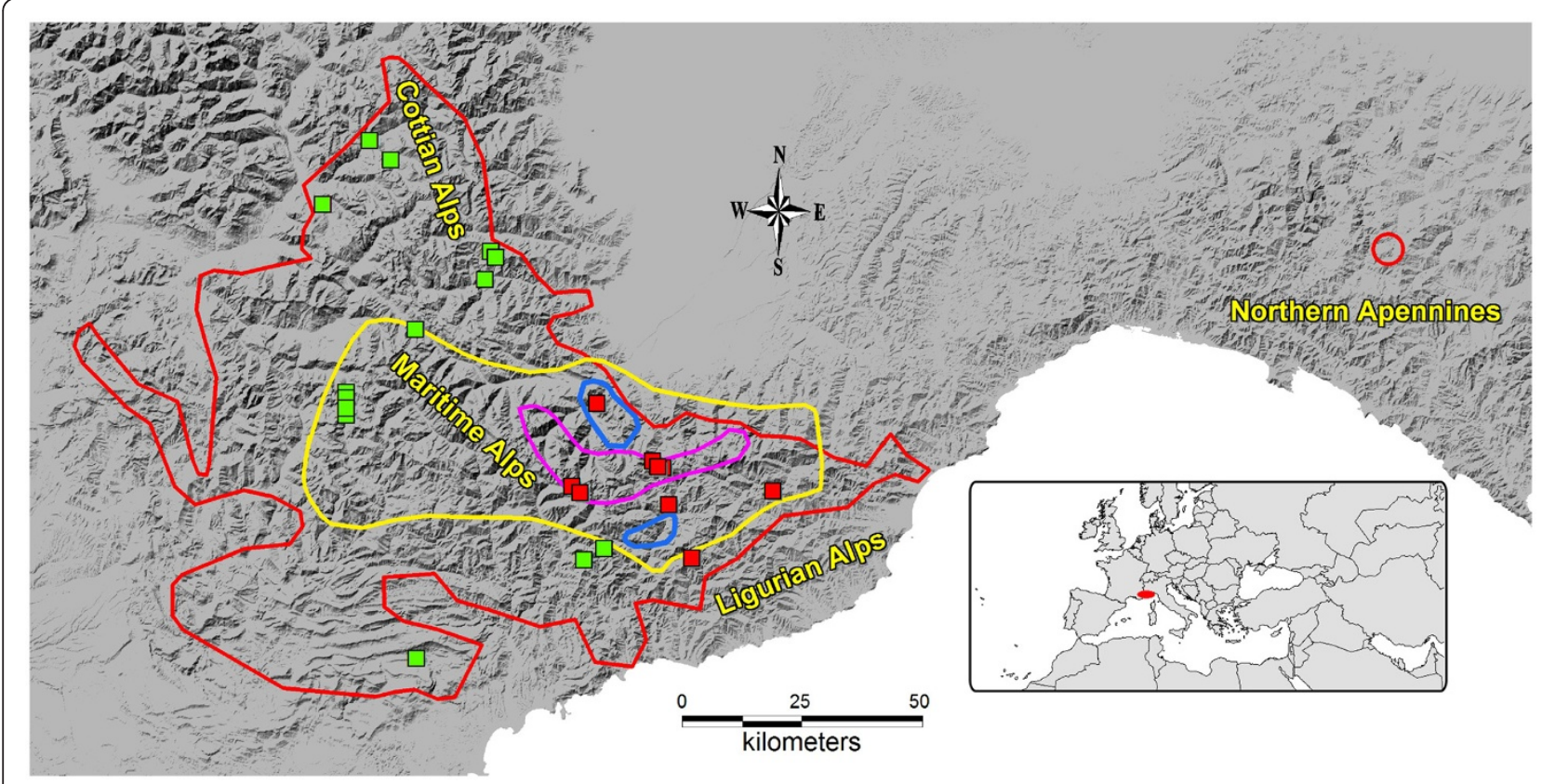

Figure 1 Geographic distribution of $P$. marginata, $P$. allionii, $P$. hirsuta and $P$. latifolia in the SW Alps. Areas of distribution of $P$. marginata (red line), P. allionii (blue line), P. hirsuta (pink line) and P. latifolia (yellow line). Cytotype distribution of P. marginata according to Kress (1969): green squares $=$ hexaploids; red squares $=$ dodecaploids. The major mountain chains in the distributional areas of the species are labeled (Cottian, Maritime and Ligurian Alps within the Western Alps; Northern Apennines). 
[33] and Kress [34], respectively? The results of our study have broader implications to elucidate the role of polyploidization in areas affected by Pleistocene glacial cycles.

\section{Results}

\section{Ploidy level survey}

Flow cytometry analyses identified two groups of populations based on relative fluorescence intensity (Table 1): one ranging from 165 to 194 (hexaploids) and the other ranging from 322 to 373 (dodecaploids). The analysis yielded high-resolution histograms, with average CV of $4.52 \%$ (range 3.54-5.26\%) for hexaploids and 4.24\% (range 3.19-5.38\%) for dodecaploids. The investigation of 100 individuals revealed no intermediate ploidy levels. In addition, we found no variation of ploidy levels within the same population.

\section{cpDNA phylogeny}

The aligned cpDNA data matrix consisted of 2334 characters (including 19 gaps coded as binary characters), of which 215 were variable (corresponding to $9 \%$ of the matrix) and 135 parsimony informative (corresponding to $6 \%$ of the matrix). The MP yielded 40 most parsimonious

Table 1 Results of flow cytometry analyses

\begin{tabular}{|c|c|c|c|c|}
\hline Population & code & $\mathbf{N}$ & $\begin{array}{l}\text { Coefficient of } \\
\text { variation } \%\end{array}$ & $\begin{array}{l}\text { Relative fluorescence } \\
\text { intesity }\end{array}$ \\
\hline \multirow[t]{9}{*}{ HEXAPLOID } & mar_1 & 5 & $4.83(0.35)$ & $165.33(3.30)$ \\
\hline & mar_2 & 8 & $3.99(0.49)$ & 177.00 (2.89) \\
\hline & mar_3 & 4 & $3.64(0.18)$ & $173.89(2.25)$ \\
\hline & mar_4 & 6 & $5.26(0.73)$ & $166.48(5.85)$ \\
\hline & mar_5 & 5 & $5.16(0.76)$ & $171.28(4.93)$ \\
\hline & mar_6 & 8 & $4.67(0.42)$ & $174.27(2.89)$ \\
\hline & mar_7 & 6 & $3.54(0.30)$ & $194.21(2.54)$ \\
\hline & mar_8 & 9 & $4.89(0.16)$ & $164.42(1.93)$ \\
\hline & mar_9 & & & \\
\hline Total hexaploid & & 51 & $4.52(0.74)$ & $173.19(9.56)$ \\
\hline \multirow[t]{9}{*}{ DODECAPLOID } & mar_10 & 6 & $5.38(0.93)$ & 333.97 (9.09) \\
\hline & mar_11 & 5 & $4.69(0.23)$ & $324.62(5.15)$ \\
\hline & mar_12 & 5 & $4.86(0.58)$ & $321.78(5.49)$ \\
\hline & mar_13 & 8 & $4.16(0.36)$ & $324.90(9.60)$ \\
\hline & mar_14 & 5 & $3.46(0.25)$ & $353.78(5.43)$ \\
\hline & mar_15 & 5 & $3.86(0.27)$ & $359.44(5.49)$ \\
\hline & mar_16 & 3 & $4.43(0.17)$ & $356.47(7.17)$ \\
\hline & mar_17 & 5 & $3.19(0.20)$ & 373.15 (4.34) \\
\hline & mar_18 & 7 & $3.75(0.48)$ & $367.04(12.06)$ \\
\hline Total dodecaploid & & 49 & $4.24(0.82)$ & $343.93(21.14)$ \\
\hline
\end{tabular}

Populations codes (as in Table 4), numbers of individual analyzed (N), coefficient of variation in percentage and relative fluorescence intensity, with standard deviation in parentheses, are reported. trees, with a consistency index $(\mathrm{CI})$ of 0.79 , a retention index (RI) of 0.87 and a rescaled consistency index (RC) of 0.69. In both BI and MP majority-rule consensus trees, all $P$. marginata accessions formed a strongly supported clade with $P$. latifolia accessions (Posterior Probability: $\mathrm{PP}=0.99$, Bootstrap Support: $\mathrm{BS}=76 \%$; Figure 2B, Additional file 1: Figure S1). The clade was divided into two parts ( 1 and 2 in Figure 2B, Additional file 1: Figure S1). Clade $1(\mathrm{PP}=1, \mathrm{BS}=92 \%)$ comprised both hexaploid (mar4,6-8) and dodecaploid (mar10-18) populations of $P$. marginata, located in the south-eastern part of its range, and two populations of $P$. latifolia (lat1,3). In clade 1 of the Bayesian phylogeny (Figure 2B), the two individuals representing populations mar10 and mar12, located on the eastern border of the range, were sister to each other $(\mathrm{PP}=0.88)$. Clade $2(\mathrm{PP}=0.98, \mathrm{BS}=$ $71 \%$ ) comprised only hexaploid populations of $P$. marginata (mar1-3,5,9), geographically located in the north-western part of its range (Figure 2A), together with two individuals of a population of $P$. latifolia (lat2; Figure 2B, Additional file 1: Figure S1).

The three accessions of $P$. allionii formed a monophyletic group ( $\mathrm{PP}=0.95, \mathrm{BS}=81 \%$ ), subtended by a long branch, that was sister to $P$. palinuri in the Bayesian tree $(\mathrm{PP}=0.79$; Figure $2 \mathrm{~B})$ and formed polytomy with the same species and the P. marginata/P. latifolia clade in the MP tree (Additional file 1: Figure S1). All analyses supported a clade formed by $P$. allionii, $P$. palinuri, P. latifolia and $P$. marginata $(\mathrm{PP}=0.98, \mathrm{BS}=66 \%$; Figure 2B, Additional file 1: Figure S1). The two samples of $P$. hirsuta, the fourth species that geographically cooccurs with $P$. marginata, were not sister to each other: hir1 formed a well-supported clade with $P$. villosa and $P$. pedemontana $(\mathrm{PP}=1, \mathrm{BS}=90 \%)$; hir2 was included in a statistically strong clade with $P$. auricula and $P$. daonensis $(\mathrm{PP}=1 ; \mathrm{BS}=100 \%$; Figure $2 \mathrm{~B}$, Additional file 1: Figure S1).

\section{nrDNA variation}

Between seven and 14 ribotypes per individual of P. marginata were detected, for a total of $147 \mathrm{nrDNA}$ sequences. The matrix included a total of 670 characters (662 aligned bps: ITS1 $=282$ bps, $5.8 \mathrm{~S}=158$ bps, ITS2 = 222 bps; and eight binary coded gaps). We found a total of 61 substitutions and two single-nucleotide gaps in the $5.8 \mathrm{~S}$ region; 126 substitutions and nine gaps, of which five were apomorphic, in the ITS1 region; and 102 substitutions and four gaps, of which two were apomorphic, in the ITS2 region. The average G-C content was 53.5\%. Only one (3SEQ) of the seven methods implemented in the analysis of recombination using RDP3 detected one statistically significant recombination event (Additional file 1: Table S6), indicating that recombinant ITS clones did not affect our analyses. 

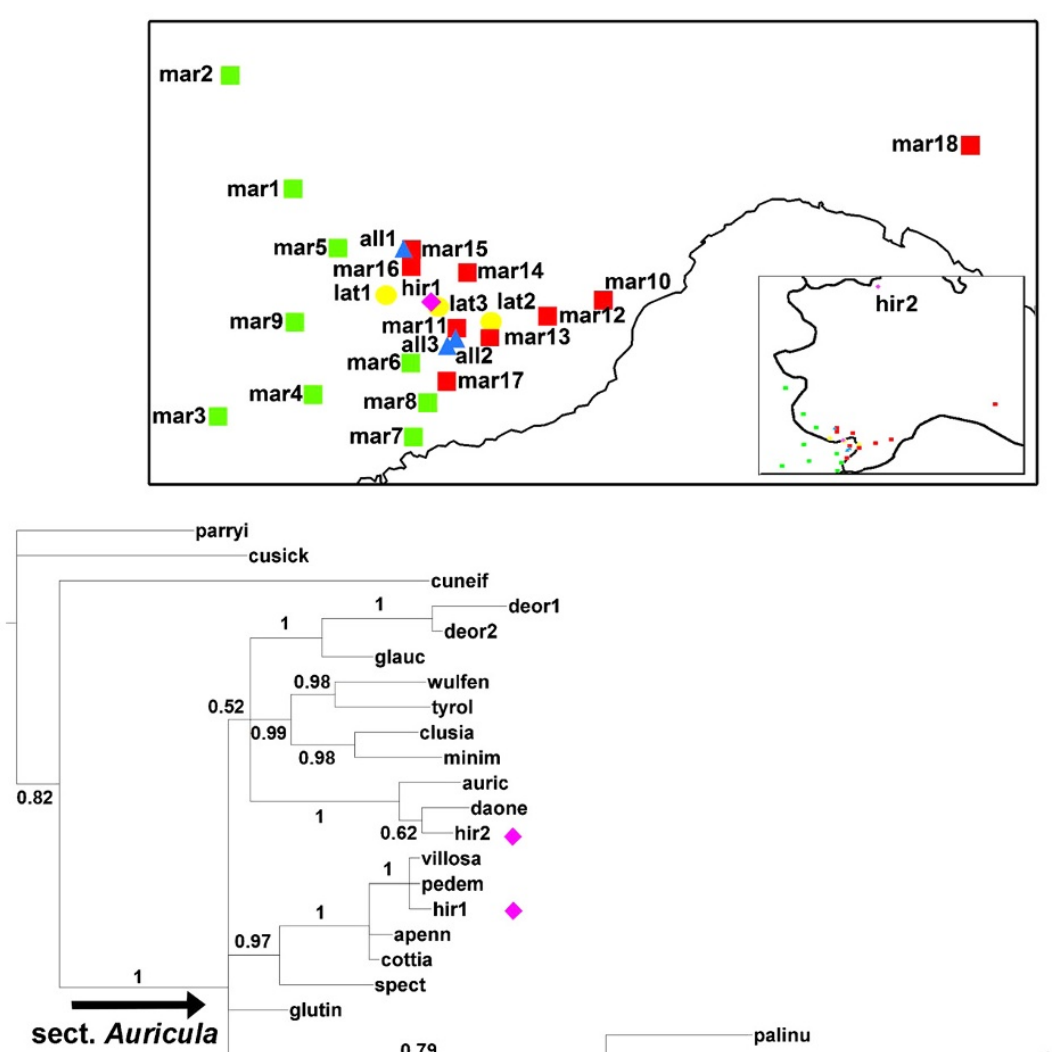

\section{A}

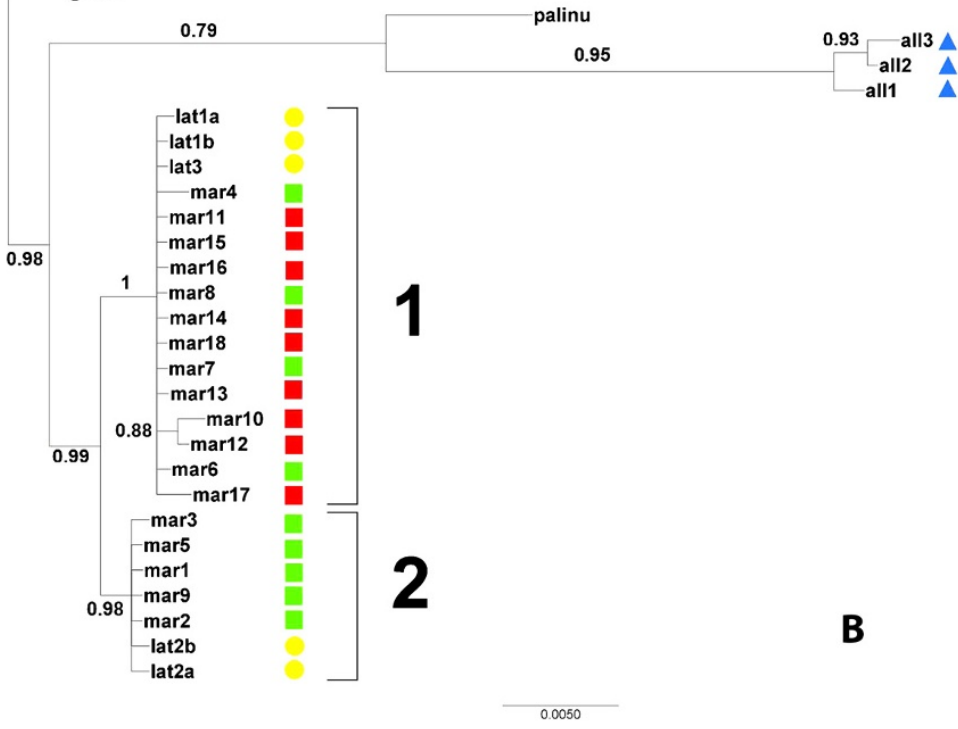

Figure 2 Geographic distribution and cpDNA tree of $P$. marginata and relatives. A) Geographic distribution of sampled populations of P. marginata, P. allionii, P. latifolia and P. hirsuta in the Western Alps and Northern Apennines; B) Bayesian 50\% majority-rule consensus tree of Primula sect. Auricula accessions; Posterior Probability (PP) values are indicated. P. marginata hexaploids $=$ green squares; $P$. marginata dodecaploids $=$ red squares; $P$. allionii $=$ blue triangles; $P$. latifolia $=$ yellow circles; $P$. hirsuta $=$ pink diamonds. Ploidy levels according to flow cytometry data of the present study (Table 1). Population codes as in Table 4 and Additional file 1.

Two hundred and ninety-seven of the 670 characters were variable, of which 127 were parsimony informative, corresponding to $18.95 \%$ of the aligned length. MP analyses of the nrDNA matrix yielded 7 most parsimonious trees, with a CI of 0.66 , RI of 0.85 and a RC of 0.56 . The consensus trees resulting from both $\mathrm{BI}$ and $\mathrm{MP}$ analyses of all cloned ribotypes were largely unresolved, with the following main exceptions (Figure 3, Additional file 1: Figure S2): I) a clade formed by all sequences of all populations of $P$. latifolia ( $\mathrm{PP}=1, \mathrm{BS}=97 \%$ ); II) a clade comprising all sequences from the all1 population of P. allionii $(\mathrm{PP}=1, \mathrm{BS}=89 \%)$; III) a clade formed by 


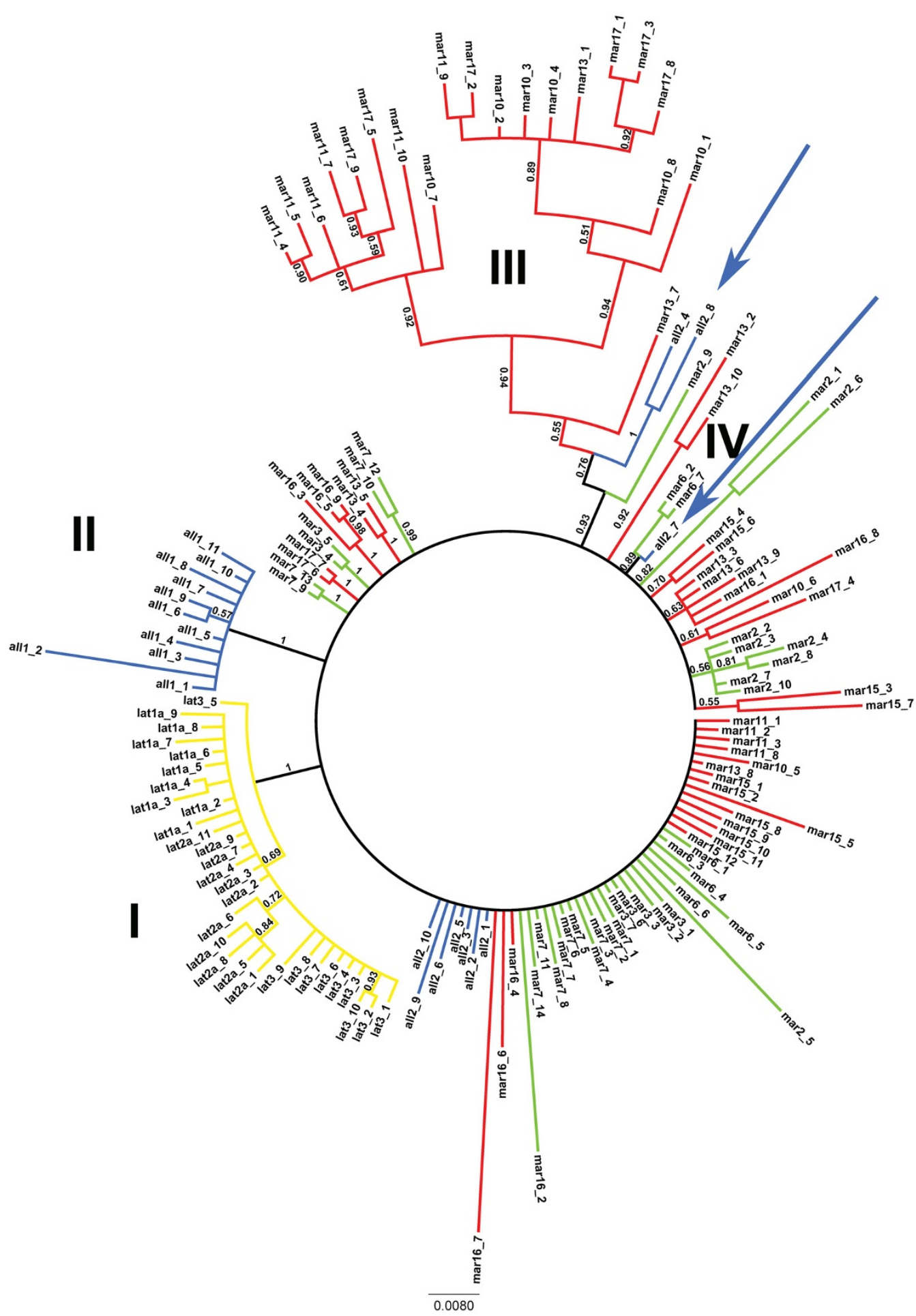

Figure 3 Bayesian 50\% majority-rule consensus tree of cloned ITS sequences. Bayesian tree inferred from cloned ITS sequences of P. marginata, P. allionii and P. latifolia. Posterior probability values are reported. The colors distinguish species and ploidy levels: $P$. marginata hexaploids $=$ green. P. marginata dodecaploids $=$ red. P. allionii $=$ blu. . . latifolia $=$ yellow. Accessions codes as in Table 4; clones are numbered progressively for each accession. Clade I: all sequences of $P$. latifolia; Clade II: all sequences from all1 population of $P$. allionii; Clade III: sequences from dodecaploid populations mar10, mar11, mar13, mar17 of P. marginata; Clade IV: sequences from the hexaploid mar6 population of P. marginata and all2 population of $P$. allionii. The two blue arrows indicate the ITS clones from individual all2 of $P$. allionii that form clades with ITS clones from P. marginata. 
Table 2 Additive polymorphisms detected in the ITS1 and ITS2 regions of $\boldsymbol{P}$. marginata, $\boldsymbol{P}$. allionii and $\boldsymbol{P}$. latifolia

\begin{tabular}{|c|c|c|c|c|c|c|c|c|c|}
\hline Ploidy & Specie & Code & 18 & 247 & 272 & 414 & 475 & 553 & 661 \\
\hline $6 x$ & P. latifolia & lat_1a & C & A & - & $\mathrm{T}$ & C & $C$ & A \\
\hline $6 x$ & & lat_2a & C & A & - & $\mathrm{T}$ & C & C & A \\
\hline $6 x$ & & lat_3 & C & A & - & $\mathrm{T}$ & C & C & A \\
\hline $6 x$ & P. allionii & all_1 & C & A & A & $\mathrm{T}$ & $\mathrm{T}$ & C & $S$ \\
\hline $6 x$ & & all_2 & $\mathbf{M}$ & A & $\mathbf{T} /-$ & $\mathbf{Y}$ & C & C & C \\
\hline $6 x$ & P. marginata & mar_2 & A & $S$ & $\mathbf{T} /-$ & $\mathbf{Y}$ & C & C & $\mathbf{M}$ \\
\hline $6 x$ & & mar_3 & $\mathbf{M}$ & M & $\mathrm{T}$ & $\mathrm{T}$ & C & C & C \\
\hline $6 x$ & & mar_6 & $\mathbf{M}$ & M & $\mathrm{T}$ & $\mathrm{T}$ & C & C & C \\
\hline $6 x$ & & mar_7 & M & M & $\mathrm{T}$ & $\mathrm{T}$ & C & C & C \\
\hline $12 x$ & & mar_10 & $\mathbf{M}$ & G & - & $\mathbf{Y}$ & $\mathbf{Y}$ & $\mathbf{Y}$ & A \\
\hline $12 x$ & & mar_11 & $\mathbf{M}$ & $\mathrm{S}$ & $\mathrm{T} /-$ & $\mathbf{Y}$ & $\mathrm{T}$ & T & M \\
\hline $12 x$ & & mar_13 & $\mathbf{M}$ & $\mathbf{v}$ & $\mathrm{T}$ & $\mathrm{T}$ & $\mathrm{T}$ & $\mathbf{Y}$ & C \\
\hline $12 x$ & & mar_15 & $\mathbf{M}$ & M & $\mathrm{T}$ & C & C & C & C \\
\hline $12 x$ & & mar_16 & $\mathbf{M}$ & M & T/- & $\mathbf{Y}$ & $\mathrm{T}$ & C & $\mathbf{M}$ \\
\hline $12 x$ & & mar_17 & $\mathbf{M}$ & $S$ & T/- & $\mathbf{Y}$ & $\mathbf{Y}$ & $\mathbf{Y}$ & M \\
\hline
\end{tabular}

Summary of additive polymorphisms (in bold) detected in the seven sites of the ITS1 and ITS2 regions of P. marginata, P. allionii and P. latifolia: ploidy levels, species names, population codes (as in Table 4), and positions of the seven sites in the aligned sequences are reported; ambiguity symbols according to IUPAC ( $\mathrm{Y}=\mathrm{C}$ or $\mathrm{T}, \mathrm{M}=\mathrm{A}$ or $\mathrm{C}, \mathrm{S}=\mathrm{C}$ or $\mathrm{G}, \mathrm{V}=\mathrm{A}$ or $\mathrm{C}$ or $\mathrm{G})$. Dashes indicate a gap. sequences from four dodecaploid, western populations of $P$. marginata (mar10,11,13,17; $\mathrm{PP}=0.55, \mathrm{BS}=52 \%$ ); in the BI tree this clade additionally clusters with two sequences from one population of $P$. allionii (all2; $\mathrm{PP}=$ 0.76) and one sequence from one hexaploid eastern population of $P$. marginata (mar2; PP $=0.93$ ); IV) a small clade including two sequences from the hexaploid mar6 population and one sequence from the all 2 population $(\mathrm{PP}=0.89, \mathrm{BS}=64 \%)$.

The matrix of cloned ITS sequences included a total of 31 additive polymorphisms in seven sites: 22 (corresponding to $70.97 \%$ of the total number) occurred in the dodecaploid accessions of $P$. marginata, whereas only six (19.35\%) belonged to $P$. marginata hexaploids and three $(9.68 \%)$ to $P$. allionii (which is consistently hexaploid). Conversely, P. latifolia sequences did not display any additive polymorphisms (Table 2).

The three first principal coordinates of the PCoA explained $44.77 \%$ of the total molecular variation of the ITS clones. The results were consistent with the general structure of the ITS tree (Figure 4), for all sequences of $P$. latifolia, some sequences of $P$. allionii, and some sequences from $P$. marginata $12 \mathrm{x}$ samples formed three well to relatively well defined clusters,

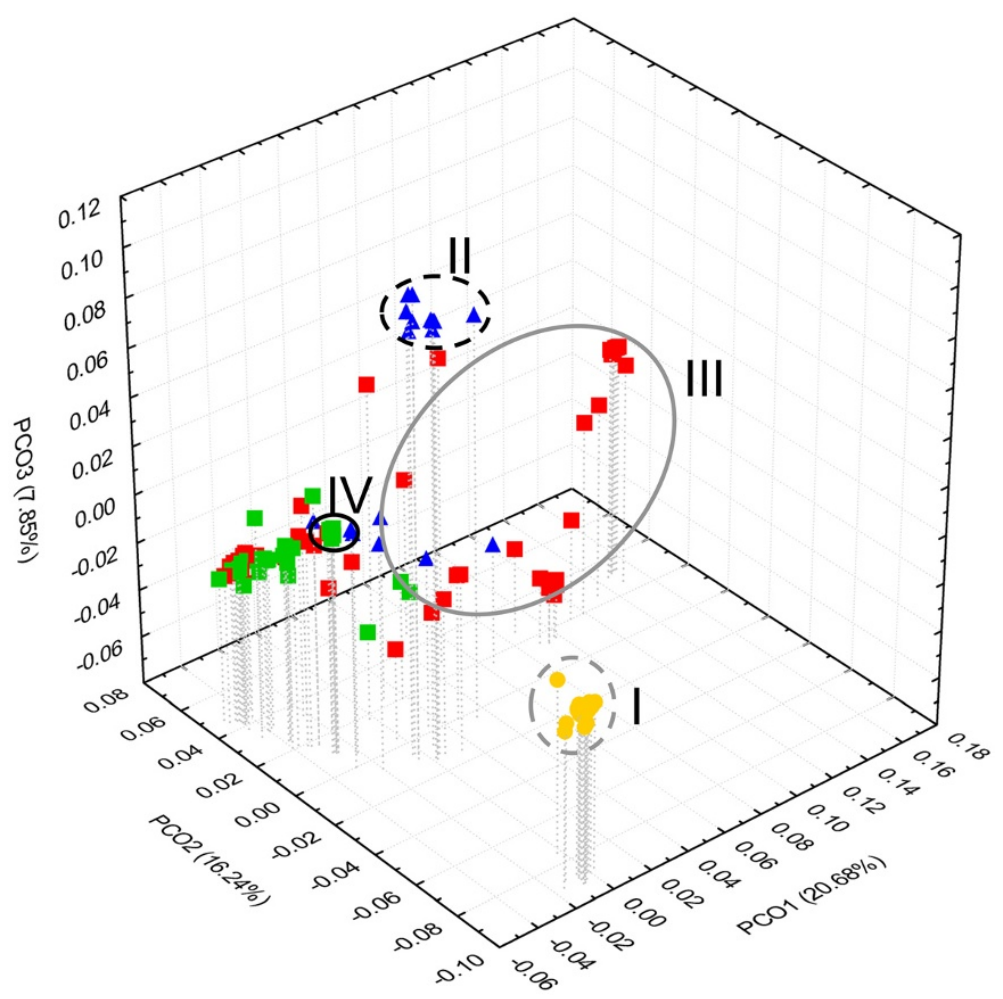

Figure 4 PCoA scatterplot of ITS clones. Scatterplot inferred from pairwise distances between cloned ITS sequences using the K2P substitution model: $P$. marginata hexaploids = green squares; $P$. marginata dodecaploids $=$ red squares; $P$. allionii $=$ blue triangles; $P$. latifolia $=$ yellow circles. Ellipses indicate clades I-IV of Figure 3. 
respectively; conversely, most other sequences from $P$. allionii and P. marginata hexaploids and dodecaploids clustered together.

The results of AMOVA (Table 3) indicated that most variation of the ITS clones is partitioned within individuals (values ranging between $69.91 \%$ and 62.30\%), regardless of how the ITS sequences are grouped. Among groups, more variation is partitioned according to taxonomic classification, with $(21.39 \%$ in H3) or without (24.01\% in H2) cytological groupings in P. marginata, than according to the clades supported by the cpDNA phylogeny $(4.33 \%$ in $\mathrm{H} 1)$.

The total nucleotide diversity of cloned ITS sequences was twice as high in $P$. marginata dodecaploids than in hexaploids $(0.032 \pm 0.016$ vs. $0.015 \pm 0.008$, respectively) The Kendall Tau statistic did not show any significant correlation between the nucleotide diversity of all $P$. marginata individuals and the number of clones per individuals $(\mathrm{r}=-0.094$; $\mathrm{p}>0.05)$ nor number of individuals per population $(\mathrm{r}=-0.193 ; \mathrm{p}>0.05)$.

\section{Discussion}

Pleistocene glacial cycles have been recognized as one of the major drivers of polyploid speciation in several alpine/arctic genera, including Cerastium, Draba, Parnassia, Saxifraga and Vaccinium [19; as reviewed in 37]. Polyploidization involving differentiated progenitors might have occurred in glacial refugia, where several species survived glacial maxima (e.g., Androsace brigantiaca [38]), or via secondary contact between populations that became isolated during glacial maxima and reconnected during interglacials [16,17], as proposed for Primula sect. Aleuritia [23].

The Pleistocene time frame for the evolution of Primula sect. Auricula inferred from both a section-wide ITS phylogeny [29] and a Primula-wide cpDNA phylogeny [De Vos \& Conti, unpublished results] suggests that glacial cycles likely influenced the origin of $P$. marginata. In the present study, we use multiple lines of evidence to

Table 3 Analysis of molecular variance (AMOVA) in cloned ITS sequences

\begin{tabular}{llll}
\hline Hypotheses & \multicolumn{3}{c}{ Percentage of variation } \\
\cline { 2 - 4 } & $\begin{array}{l}\text { among } \\
\text { groups }\end{array}$ & $\begin{array}{c}\text { among individuals } \\
\text { within groups }\end{array}$ & $\begin{array}{c}\text { within } \\
\text { individuals }\end{array}$ \\
\hline $\mathrm{H} 1$ & $4.33^{\mathrm{NS}}$ & $25.76^{*}$ & $69.91^{*}$ \\
$\mathrm{H} 2$ & $24.01^{*}$ & $13.69^{*}$ & $62.30^{*}$ \\
$\mathrm{H} 3$ & $21.39^{*}$ & $11.31^{*}$ & $67.30^{*}$ \\
\hline
\end{tabular}

AMOVA was used to test whether variation was partitioned among groups that corresponded to: $\mathrm{H} 1$ ) the clades of the cpDNA phylogeny (i.e., $P$. marginata/P. latifolia clades and $P$. allionii clade); $\mathrm{H} 2$ ) current taxonomical classification (P. marginata, P. latifolia and P. allionii); $\mathrm{H} 3$ ) taxonomical classification with the subdivision of $P$. marginata in two cytotypes ( $P$. marginata dodecaploids, $P$. marginata hexaploids, $P$. latifolia and $P$. allionii).

${ }^{*}=\mathrm{P}$ value $<0.01{ }^{\mathrm{NS}}=$ not significant. reconstruct the likely evolutionary history of $P$. marginata in relation to Pleistocene climate-dynamics. Our combined results allow us to propose possible superimposed processes that left distinctive signatures on the distribution of cytotypes and phylogenetic structure of the $P$. marginata chloroplast and nuclear genomes, suggesting events that might have occurred at different points in the evolution of the lineage. The complementarity of information between cytotype variation and nuclear and organellar genomes has proven indispensible to elucidate complex evolutionary histories in other boreal taxa, e.g. Vaccinium [39], Artemisia [40], and Nymphaea [41].

Flow cytometric analyses (Table 1) allowed us to expand the relatively limited, available information on cytotype variation (e.g., 41 individuals from 11 localities; $[31,33,34])$ to a survey of 100 individuals from 17 populations of $P$. marginata. Failure to detect any intermediate cytotypes nor any variation of ploidy levels within populations (Table 1) are congruent with the preliminary results of crossing experiments suggesting reproductive incompatibilities between the two cytotypes [Minuto et al., unpublished results]. Our investigations also enable us to confirm that the hexaploid and dodecaploid populations of $P$. marginata occur primarily in the western and eastern parts, respectively, of the species' distributional range (Figure 2A).

Both adaptive and non-adaptive processes can explain the infra-population uniformity of cytotypes and their geographic separation. In the adaptive scenario, novel genetic combinations in the polyploids may allow them to adapt to different environmental conditions corresponding to specific geographic areas $[7,13]$. In the nonadaptive scenario, hybridization between cytotypes is thought to be either non-viable or produce plants with lower fitness, gradually leading to the elimination of the minority cytotype through frequency-dependent mechanisms ('minority cytotype exclusion model', [42]). These non-adaptive processes, while producing cytological uniformity, promote differentiation in a stochastic manner that does not usually produce distinct morphological and ecological characteristics $[43,44]$. In $P$. marginata the lack of morphological distinctiveness of the two cytotypes [25] and the absence of any obvious new ecological preferences in the dodecaploids [34] all fit the predictions of the nonadaptive scenario.

The two cytotypes of $P$. marginata do not form distinct clades either in the cpDNA or in the nrDNA phylogenies (Figures 2B, Figure 3), a pattern that seems more congruent with the stochastic nature of nonadaptive processes than with a scenario implying divergence between cytotypes adapted to distinct ecological conditions in different parts of the species range $[13,42]$. Despite the lack of reciprocal monophyly between the western, hexaploid and the eastern, dodecaploid 
populations, respectively, a signal of some geographic structure is detectable in the cpDNA topology. In this tree, the sequences of five hexaploid populations from the western part of the $P$. marginata range form a clade with a population of $P$. latifolia located further to the East (lat2; Figure 2B, clade 2), and a mixture of sequences from hexaploid and dodecaploid $P$. marginata populations eastward of the previously mentioned ones form a clade with two other samples of $P$. latifolia (Figure $2 \mathrm{~B}$, clade 1 ). The sharing of cpDNA haplotypes between $P$. marginata and $P$. latifolia might be explained by reticulation or incomplete lineage sorting from a polymorphic ancestor $[45,46]$. These processes are not necessarily mutually exclusive and are difficult to disentangle. However, assuming that the DNA sequences under exam are not under selection, a geographical pattern, as observed in our case, more likely results from introgression than lineage sorting [47].

In light of the non-adaptive scenario invoked above to explain the spatial separation between hexaploid and dodecaploid populations of $P$. marginata and the Pleistocene time frame for the evolution of Primula sect. Auricula [29; deVos, unpublished results], it is plausible to propose that abiotic processes, likely involving range fragmentation and/or shift during glacial maxima, contributed to the geographic signature in the cpDNA tree. More specifically, the clustering of all sampled dodecaploid populations of $P$. marginata with hexaploid populations from the southern portion of its distribution (Figure 2B clade 1), located in the glacial refugium of the Maritime Alps [48-50], might indicate that refugial populations from this area likely played a role in the origin of the dodecaploids. This explanation of geographic structure in the cpDNA phylogeny is consistent with the general interpretation of refugia on the southern side of the Alps as reservoirs of evolutionary potential during the climatic oscillations of the Pleistocene $[29,38,48,50-54]$. To summarize, the cpDNA tree indicates that, among the species of sect. Auricula that co-occur in the western Alps and are known to form hybrids with $P$. marginata either in nature or in cultivation $[25,30]$, the latter shares a more recent common ancestor with $P$. latifolia than with $P$. allionii or $P$. hirsuta, while it excludes a close relationship with the allopatric P. auricula [33].

The nrDNA tree does not corroborate the common ancestry between $P$. marginata and $P$. latifolia supported by the cpDNA topology. The greater partitioning of ITS variation according to taxonomic groups $(21.39 \%$ and 24.01\%) than to the clades supported by the cpDNA phylogeny (4.33\%; Table 3 ) provides a further indication of the topological conflict between the two phylogenies. In the nuclear phylogeny, all sequences from three populations of $P$. latifolia are included in a monophyletic group, while those of $P$. marginata and $P$. allionii are unresolved. Some sequences from a southern population of $P$. allionii (all2) share more recent common ancestors with sequences from hexaploid or dodecaploid populations of P. marginata (clades III, IV; Fig. 3) than with sequences from a northern population of $P$. allionii (all1), which form a well-supported clade (clade II; Figure 3). The non-monophyly of ribotypes from the same species may result from introgression between P. marginata-like and P. allionii-like ancestors, eventually leading to the homogenization of all2 sequences towards the $P$. marginata ribotypes. The interdigitation of nrDNA sequences in the phylogeny is reflected in the lack of distinct species clusters in the corresponding PCoA scatterplot (Figure 4). Congruently, most ITS variation is allocated within individuals (62.30-69.91\%) rather than between groups in the AMOVA (Table 3). Our results also contradict the sister relationship between P. marginata and P. latifolia supported by one of 7770 equally parsimonious trees derived from direct sequencing of ITS amplicons in a previous study, where no cloning was performed [29]. In summary, nuclear ribotypes from different individuals of a $P$. allionii population located in the southern refugium of the Roya Valley in the Maritime Alps [49] and some hexaploid and dodecaploid populations of $P$. marginata coalesced more recently than haplotypes within the respective species, indicating a close and complex evolutionary history for their nuclear genomes.

Discrepancies between the phylogenetic signal of chloroplast and nuclear genomes have been found in several other polyploid complexes of the Northern hemisphere (e.g., Vaccinium uliginosum [39], Primula sect. Aleuritia [23], Cerastium [55], Viola [56]; see review in [19]). Explanations for cytonuclear conflicts range from differential substitution rates between the two genomes, hybridization/introgression, paralogy and incomplete homogenization or lineage sorting, especially of the nuclear sequences, or a combination of various processes [57-61]. Reciprocal illumination between different lines of evidence may help to favour some explanations over others. For instance, the neutral theory of molecular evolution [62] predicts that nuclear sequences should take longer to coalesce than organellar sequences, due to the larger, genetically effective population size of the former, especially in polyploid species [63,64]. Conversely, concerted evolution is supposed to speed the homogenization of multiple copies, as in the nrDNA region $[59,65,66]$. Another observation relevant to the interpretation of discrepancies between cpDNA and nrDNA phylogenies is that cpDNA sequences tend to evolve more slowly than ITS sequences, thus the former might be more suitable to track deeper evolutionary events, while the latter might better capture the phylogenetic 
signature of more recent events (e.g., [39,67]). Therefore, our phylogenetic results, taken together, seem compatible with the hypothesis of an initial homoploid introgression of the chloroplast genome between a $P$. latifolia-like ancestor and a $P$. marginata lineage, resulting in the persistence of cpDNA sequences that are more closely related to heterospecific than conspecific sequences (Figure 2B). The initial episode of chloroplast capture was probably followed by the separation between western and eastern populations of $P$. marginata, possibly driven by advancement of glaciers during glacial maxima, and the subsequent origin of the dodecaploids (Figure 2A). The occurrence of ITS clones from the all2 population of $P$. allionii in clades with dodecaploid and hexaploid individuals of $P$. marginata suggests that an ancestral southern population located in the Roya Valley, which was ice free in the Last Glacial Maximum [49], might have played a crucial role in the origin of $P$. marginata dodecaploids (Figure 2A, Figure 3). However, the lack of intermediate cytotypes in $P$. marginata (Table 1 ) and of any admixed individuals in an AFLP survey of $P$. marginata and $P$. latifolia [30] implies that the three species might have been evolutionarily isolated more recently, an interpretation also proposed by Kadereit et al. [30].

The higher proportion of ITS additive polymorphisms in dodecaploid than in hexaploid accessions of $P$. marginata (71\% vs. $19.3 \%$, respectively; Table 2 ) and higher total nucleotide diversity of ITS clones in the sequences of dodecaploid vs. hexaploid individuals ( 0.032 vs. 0.015$)$ are congruent with an allopolyploid explanation for the origin of the dodecaploid populations of this primrose [68]. At the same time, the occurrence of shared additivity between $P$. allionii and $P$. marginata suggests a role of the former in the evolutionary history of the latter. The allopolyploid interpretation for the origin of $P$. marginata dodecaploids might appear to conflict with their lack of morphological differentiation [25,34; Casazza, unpublished observations]. Our case study might represent an example where the allopolyploids resemble one of the putative parental lineages, a situation that has been found also in Mimulus [69] and Centaurea toletana [70; as reviewed in 10] and is compatible with the non-adaptive scenario $[43,44]$ proposed above to explain the geographic separation between hexaploid and dodecaploid populations.

\section{Conclusions}

Taken together, our results suggest that the dodecaploids of $P$. marginata are most likely of allopolyploid origin, as already proposed by Favarger [33], and that their origin is probably best interpreted within the context of glacial cycles during the Pleistocene, as proposed for the evolution of polyploids in Primula sect. Aleuritia [23]. While cpDNA introgression from a $P$. latifolia-like to a
P. marginata-like lineage might have occurred earlier, subsequent hybridization events between southern refugial populations of hexaploid $P$. allionii-like and $P$. marginata-like ancestors were probably responsible for the origin of dodecaploid populations in the latter. Our study thus further underscores the important role of southern refugia, specifically in the Maritime Alps, as cradles of new biological diversity during the Pleistocene glaciations, as suggested also for other plant groups (e.g., Carabus solieri [52], Saxifraga callosa [71], Androsace brigantiaca [38]).

The adaptive vs. non-adaptive nature of the processes leading to the establishment of polyploids has different taxonomic consequences. In the adaptive scenario, the newly formed polyploids are adapted to specific ecological conditions and often display correspondingly distinct morphological characteristics, thus justifying the assignment of the different cytotypes to separate taxonomic units. Conversely, in the non-adaptive scenario, the frequent lack of any distinctive ecological or morphological features between cytotypes does not allow for any clear taxonomic differentiation. Therefore, the current evolutionary state of the hexaploid and dodecaploid cytotypes in $P$. marginata does not warrant taxonomic distinction, as already observed in other species (e.g., [43,44,68,72]). However, if the dodecaploids of $P$. marginata continue to remain reproductively isolated from the hexaploids of the same species and from $P$. allionii, as implied by the absence of intermediate cytotypes in their populations, over time they might differentiate from their relatives also morphologically, eventually leading to the origin of a taxonomically diagnosable species.

\section{Methods}

\section{Sampling procedures}

To investigate variation of ploidy levels in $P$. marginata, we collected three to eight individuals from each of 17 populations covering its entire distributional range (Table 4, Figure 2A). A total of 100 transplanted individuals were cultivated at the Botanical Garden of the University of Genova and later used for flow cytometry analyses at the Institute of Systematic Botany of the University of Zurich.

To investigate the phylogenetic relationships of $P$. marginata, we collected and dried leaf tissue in silica gel from several populations of $P$. marginata, $P$. latifolia, $P$. allionii, $P$. hirsuta, and related species in Primula sect. Auricula. To provide a broader phylogenetic context for the relationships of $P$. marginata, we also sampled 16 accessions from 15 species of sect. Auricula for the cpDNA analyses. Additionally, three taxa were selected for outgroup rooting based on published phylogenetic studies of Primula [29,73]: P. cuneifolia (sect. 
Table 4 Sampling of $P$. marginata and co-occurring species of Primula sect. Auricula from the Western Alps

\begin{tabular}{|c|c|c|c|c|c|c|c|}
\hline Species & locality & lat $\mathrm{N}$ & long $\mathrm{E}$ & code & Flowcytometry & cpDNA & nrDNA \\
\hline \multirow[t]{3}{*}{ P. allionii } & Vallone Scumbes, Val Gesso, Italy & $44^{\circ} 17^{\prime} 22^{\prime \prime}$ & $07^{\circ} 24^{\prime} 07^{\prime \prime}$ & all1 & & 1 & 1 \\
\hline & Saint Dalmas de Tende, Vallée de la Roya, France & $44^{\circ} 03^{\prime} 13^{\prime \prime}$ & $07^{\circ} 35^{\prime} 26^{\prime \prime}$ & all2 & & 1 & 1 \\
\hline & Chiarin, Vallée de la Roya, France & $44^{\circ} 02^{\prime} 06^{\prime \prime}$ & $07^{\circ} 33^{\prime} 34^{\prime \prime}$ & all3 & & 1 & \\
\hline \multirow[t]{2}{*}{ P. hirsuta } & Rocca dell'Abisso, Val Vermenagna, Italy & $44^{\circ} 08^{\prime} 24^{\prime \prime}$ & $07^{\circ} 31^{\prime} 37^{\prime \prime}$ & hir1 & & 1 & \\
\hline & Colle del Turlo, Val Sesia, Italy & $45^{\circ} 54^{\prime} 09^{\prime \prime}$ & $07^{\circ} 57^{\prime} 28^{\prime \prime}$ & hir2 & & 1 & \\
\hline \multirow[t]{5}{*}{ P. latifolia } & Lago della Rovina, Val Gesso, Italy & $44^{\circ} 10^{\prime} 25^{\prime \prime}$ & $07^{\circ} 20^{\prime} 21^{\prime \prime}$ & lat1a & & 1 & 1 \\
\hline & & & & lat1b & & 1 & \\
\hline & Riserva delle Navette, Val Tanarello, Italy & $44^{\circ} 06^{\prime} 11^{\prime \prime}$ & $07^{\circ} 43^{\prime} 04^{\prime \prime}$ & lat2a & & 1 & 1 \\
\hline & & & & lat2b & & 1 & \\
\hline & Rocca dell'Abisso, Val Vermenagna, Italy & $44^{\circ} 08^{\prime} 24^{\prime \prime}$ & $07^{\circ} 31^{\prime} 37^{\prime \prime}$ & lat3 & & 1 & 1 \\
\hline \multirow[t]{19}{*}{ P. marginata } & Chialvetta, Val Maira, Italy & $44^{\circ} 26^{\prime} 56^{\prime \prime}$ & $06^{\circ} 59^{\prime} 53^{\prime \prime}$ & $\operatorname{mar} 1$ & 5 & 1 & \\
\hline & Château Queyras, Vallée du Queyras, France & $44^{\circ} 44^{\prime} 40^{\prime \prime}$ & $06^{\circ} 46^{\prime} 11^{\prime \prime}$ & mar2 & 8 & 1 & 1 \\
\hline & Saint Auban, Vallée de l'Esteron, I'France & $43^{\circ} 51^{\prime} 16^{\prime \prime}$ & $06^{\circ} 43^{\prime} 29^{\prime \prime}$ & mar3 & 4 & 1 & 1 \\
\hline & Mont Bruna, Vallée de l'Esteron, I'France & $43^{\circ} 54^{\prime} 41^{\prime \prime}$ & $07^{\circ} 14^{\prime} 15^{\prime \prime}$ & mar4 & 6 & 1 & \\
\hline & Riofreddo, Valle Stura, Italy & $44^{\circ} 17^{\prime} 39^{\prime \prime}$ & $07^{\circ} 09^{\prime} 43^{\prime \prime}$ & mar5 & 5 & 1 & \\
\hline & L'Authion, Vallée de la Bevera, France & $43^{\circ} 59^{\prime} 36^{\prime \prime}$ & $07^{\circ} 25^{\prime} 36^{\prime \prime}$ & mar6 & 8 & 1 & 1 \\
\hline & Mont Baudion, Vallon de Paillon, France & $43^{\circ} 48^{\prime} 02^{\prime \prime}$ & $07^{\circ} 26^{\prime} 10^{\prime \prime}$ & mar7 & 6 & 1 & 1 \\
\hline & Cime du Grand Braus, Vallée de la Bevera, France & $43^{\circ} 53^{\prime} 27^{\prime \prime}$ & $07^{\circ} 29^{\prime} 20^{\prime \prime}$ & mar8 & 9 & 1 & \\
\hline & Beuil, Vallée du Var, France & $44^{\circ} 06^{\prime} 00^{\prime \prime}$ & $07^{\circ} 00^{\prime} 15^{\prime \prime}$ & mar9 & & 1 & \\
\hline & Rocca Barbena, Valle del Neva, Italy & $44^{\circ} 09^{\prime} 28^{\prime \prime}$ & $08^{\circ} 07^{\prime} 39^{\prime \prime}$ & mar10 & 6 & 1 & 1 \\
\hline & Colle di Tenda, Val Vermenagna, Italy & $44^{\circ} 09^{\prime} 15^{\prime \prime}$ & $07^{\circ} 35^{\prime} 34^{\prime \prime}$ & mar11 & 5 & 1 & 1 \\
\hline & Monte Galero, Val Pennavaira, Italy & $44^{\circ} 06^{\prime} 58^{\prime \prime}$ & $07^{\circ} 55^{\prime} 30^{\prime \prime}$ & mar12 & 5 & 1 & \\
\hline & Monte Saccarello, Valle Tanaro, Italy & $44^{\circ} 03^{\prime} 41^{\prime \prime}$ & $07^{\circ} 42^{\prime} 52^{\prime \prime}$ & $\operatorname{mar13}$ & 8 & 1 & 1 \\
\hline & Val Cravina, Val Pesio, Italy & $44^{\circ} 13^{\prime} 48^{\prime \prime}$ & $07^{\circ} 37^{\prime} 58^{\prime \prime}$ & mar14 & 5 & 1 & \\
\hline & Grotta del Bandito, Val Gesso, Italy & $44^{\circ} 17^{\prime} 24^{\prime \prime}$ & $07^{\circ} 25^{\prime} 44^{\prime \prime}$ & $\operatorname{mar} 15$ & 5 & 1 & 1 \\
\hline & Gorgie della Reina, Val Gesso, Italy & $44^{\circ} 14^{\prime} 44^{\prime \prime}$ & $07^{\circ} 25^{\prime} 41^{\prime \prime}$ & mar16 & 3 & 1 & 1 \\
\hline & Testa d'Alpe, Val Nervia, Italy & $43^{\circ} 56^{\prime} 45^{\prime \prime}$ & $07^{\circ} 33^{\prime} 28^{\prime \prime}$ & mar17 & 5 & 1 & 1 \\
\hline & Groppo Rosso, Val d'Aveto, Italy & $44^{\circ} 33^{\prime} 43^{\prime \prime}$ & $09^{\circ} 27^{\prime} 58^{\prime \prime}$ & mar18 & 7 & 1 & \\
\hline & & & & & 100 & 28 & 15 \\
\hline
\end{tabular}

Species, localities, coordinates (lat N, long E), population codes, and the number of individuals used for each kind of analysis (flow cytometry, cpDNA and nrDNA) are reported. All individuals collected in nature are cultivated at the Botanical Garden of the University of Genova. The 19 additional accessions for cpDNA phylogeny were reported in Additional file 1: Table S1.

Cuneifolia) and P. parryi and P. cusickiana (sect. Parryi). Therefore, a total of 47 accessions were used for cpDNA analysis. A total of 15 accessions belonging to selected populations of $P$. marginata, $P$. allionii and $P$. latifolia were used for nrDNA analysis (Table 4). Samples used in all analyses and GenBank/EBI accession numbers are listed in Table 4, Additional file 1: Tables S2, Additional file 1: Table S3,

\section{Flow cytometry}

Flow-cytometric analyses were performed on fresh leaf tissue from a total of 100 individuals (Table 4). The haploid DNA content of Pisum sativum $(1 \mathrm{C}=4.88 \mathrm{pg},[74,75])$ was used as internal standard. Approximately $1 \mathrm{~cm}^{2}$ of $P$. marginata leaf tissue was chopped together with the same quantity of $P$. sativum in $1 \mathrm{ml}$ of ice-cold Otto I buffer [76], modified as follows: $0.1 \mathrm{M}$ citric acid, $0.5 \%$ Triton-X. The suspension was filtered through nylon mesh and centrifuged at 2000 RPM for $5 \mathrm{~min}$. The pellet was resuspended in $40 \mu \mathrm{l}$ of fresh Otto I buffer. The samples were stained with $160 \mu \mathrm{l}$ of Otto II buffer $\left(0.4 \mathrm{M} \mathrm{Na}_{2} \mathrm{HPO}_{4}\right)$ supplemented with $1 \mu \mathrm{g} / \mu \mathrm{l}$ DAPI (Sigma-Aldrich, Basel, Switzerland) for $20 \mathrm{~min}$ at room temperature and analyzed with the flow cytometer Cell Lab Quanta ${ }^{\mathrm{Tm}}$ SC MPL (Beckman Coulter International S. A., Nyon, Switzerland). Isolated nuclei were excited by a Mercury arc UV lamp and the fluorescence 
intensity of 20000 nuclei was recorded. Ploidy levels were estimated according to the principle that peaks vary proportionally to the DNA content [77].

\section{DNA extraction, PCR amplification, cloning and sequencing}

Total DNA was extracted from leaf tissue using the DNeasy Plant Mini Kit (Qiagen AG, Hombrechtikon, Switzerland), following the manufacturer's instructions. The spacers $n d h F-r p l 32, p s b D-\operatorname{trn} T, \operatorname{trn} D-\operatorname{trn} T$ of the cpDNA were amplified using primers (rpL32-R, ndhF; psbD, $\operatorname{trn} \mathrm{T}^{(\mathrm{GGU})}-\mathrm{R}$; $\left.\operatorname{trn}^{(\mathrm{GGU})}, \operatorname{trnD}^{(\mathrm{GUC})} \mathrm{F}\right)$ and protocols designed by Shaw et al. [78,79]. Amplification consisted of $5 \mathrm{~min}$ at $80^{\circ} \mathrm{C}$ followed by 30 cycles of: $1 \mathrm{~min}$ denaturation $\left(95^{\circ} \mathrm{C}\right), 1 \mathrm{~min}$ annealing $\left(50^{\circ} \mathrm{C}\right)$, followed by a ramp of $0.3^{\circ} \mathrm{C} / \mathrm{sec}$ to $65^{\circ} \mathrm{C}$, and 4 min extension $\left(65^{\circ} \mathrm{C}\right)$. After the last cycle the temperature was kept at $65^{\circ} \mathrm{C}$ for the last $5 \mathrm{~min}$ of extension. A preliminary study that included two individuals per population of $P$. marginata detected no intra-population differences between the selected cpDNA target regions, therefore only one individual per population was included in subsequent cpDNA analyses.

The nuclear regions ITS1 and ITS2 were amplified using primers ITS-4 and ITS-Leu and protocols of Baum et al. [80]. Amplification reactions were performed in a total volume of $20 \mu \mathrm{l}$, adding $1 \mu \mathrm{l}$ of DNA, $1 \mathrm{x}$ buffer (containing $\mathrm{MgCl}_{2}$ ), $2 \mathrm{mM} \mathrm{MgCl}_{2}, 0.2 \mathrm{mM}$ dNTP's, 0.2 $\mu \mathrm{M}$ of each primer, 1 unit of Taq Polymerase. The final concentration of $\mathrm{MgCl}_{2}$ was $3 \mathrm{mM}$. To decrease the formation of secondary structures and the amplification of pseudogenes, $5 \%$ of dimethyl sulfoxide (DMSO) was added to the amplification mixture, as recommended by Álvarez \& Wendel [57]. Amplification consisted of 2 min at $94^{\circ} \mathrm{C}$ followed by 35 cycles of: $30 \mathrm{sec}$ denaturation $\left(94^{\circ} \mathrm{C}\right), 60 \mathrm{sec}$ annealing $\left(52^{\circ} \mathrm{C}\right)$, and $105 \mathrm{sec}$ extension $\left(72^{\circ} \mathrm{C}\right)$. After the last cycle the temperature was kept at $72^{\circ} \mathrm{C}$ for the last $10 \mathrm{~min}$ of extension and then lowered to $4^{\circ} \mathrm{C}$.

To check for intra-individual variation of ITS repeats, we cloned ITS from one individual each of ten populations of $P$. marginata, three populations of $P$. latifolia, and two populations of $P$. allionii (Table 4). To reduce the risk of preferential amplification of ITS copies, a phenomenon known as PCR-drift or PCR-bias [81], the products of two PCR reactions per individual were combined and used for ligations. PCR products were column-cleaned with the NucleoSpin ${ }^{\circledR}$ Exctract II kit (Macherey-Nagel AG, Oensingen, Switzerland) and cloned using the CloneJET ${ }^{\mathrm{TM}}$ PCR Cloning Kit (Fermentas $\mathrm{GmbH}$, Le Mont-sur-Lausanne, Switzerland), following the manufacturer's instructions, but halving the recommended amounts of reagents. One Shot ${ }^{\circledR}$ MAX Efficiency ${ }^{\circledR} \mathrm{DH} 5 \alpha^{\mathrm{TM}}-\mathrm{T} 1^{\mathrm{R}}$ Competent Cells (Invitrogen
AG, Basel, Switzerland) were used for transformation. The plasmid vector pJET was added to the cells, and these were shocked at $42^{\circ} \mathrm{C}$ for 30 seconds. After addition of $125 \mathrm{ml}$ of LB medium, cells were incubated at $37^{\circ} \mathrm{C}$ for one hour and then spread on $50 \mu \mathrm{g} / \mathrm{ml}$ Ampicillin-agar plates. Twenty colonies per cloning reaction were selected to be PCR-amplified and then sequenced using the pJET1.2 primers.

All PCR products were cleaned by adding $1 \mu \mathrm{l}$ of Calf Intestine Alcaline Phosphatase (CIAP) and $0.5 \mu \mathrm{l}$ of Exonuclease I (Fermentas $\mathrm{GmbH}$, Le Mont-sur-Lausanne, Switzerland) to each sample at $37^{\circ} \mathrm{C}$ for $15 \mathrm{~min}$, followed by $15 \mathrm{~min}$ at $94^{\circ} \mathrm{C}$ to denature the enzymes. Cycle sequencing reactions were performed with the ABI Prism BigDye Terminator Cycle Sequencing Ready Reaction Kit (Applied Biosystems, Rotkreuz, Switzerland), using 1 $\mu \mathrm{l}$ of BigDye terminator per reaction. Cycle-sequencing products were purified on 96-well multiscreen filtration plates (Millipore, Zug, Switzerland) to remove unincorporated BigDye terminator and then analyzed on an ABI 3100 Genetic Analyzer (Applied Biosystems, Foster City, $\mathrm{CA}$ ). The obtained sequences were edited and assembled using Sequencher 4.2 software (Gene Codes Corp., Ann Arbor, Michigan, USA).

\section{Alignment and phylogenetic analyses}

All sequences of the three cpDNA regions were concatenated to form a single matrix. For the nrDNA matrix, the boundaries between the ITS1, 5.8S, and ITS2 sequences were determined by reference to Rhododendron kanehirai (GeneBank Z00044, [23]). Sequences in the cpDNA and nrDNA matrices were aligned with MUSCLE [82]; the resulting alignments were adjusted by eye in MacClade 4.06 [83]. Gaps were coded as binary characters with GapCoder [84] and added at the end of the cpDNA and nrDNA matrices. Ambiguous $1 \mathrm{bp}$ indels at the end of microsatellite regions were excluded from further analyses.

Phylogenies were inferred from the cpDNA and nrDNA matrices independently using both Maximum Parsimony (MP) and Bayesian Inference (BI). MP trees were inferred in PAUP 4.0b10 [85]. A heuristic search was performed with 100 random addition sequences, 10 trees held at each step, TBR branch swapping, MULTREES option off and "steepest descent" and "allswap" on. Maxtrees was set to 10000 with no autoincrease. Branch support was estimated with 1000 bootstrap replicates, using the TBR branch swapping algorithm and the same options as above.

For $\mathrm{BI}$, the cpDNA matrix was partitioned into the three spacers while the nrDNA matrix was not partitioned. Models of nucleotide substitution were selected using an Akaike Information Criterion (AIC, [86]) in MrModeltest 2.3 [87]. The best model selected for the 
ITS matrix was the SYM $+\Gamma$ model (Additional file 1: Table S4). For cpDNA spacers matrix, MrModeltest selected the GTR $+\Gamma$ model for $p s b D$-trnT, the GTR + I $+\Gamma$ model for the ndhF-rpl32, and the HKY $+\mathrm{I}+\Gamma$ model for the trnD-trnT. Since the models selected for the two last regions could lead to parameter interaction, which might cause difficulty in reaching stationarity [88], we tested six different combinations of models (Additional file 1: Table S5) to choose the parameters that would best fit the data for these two genetic markers. Each analysis of the six different combinations was implemented in MrBayes v. 3.1.2 [89] on the Cipres Portal [90] and consisted of three to four runs of 10000000 generations from a random starting tree, with three heated and one cold chain, temperature set to 0.5 , and trees sampled from the posterior probability distribution every 1000 generations. Convergence of the chains and stationarity were assessed in Tracer 1.5 [91], examining the plot of all parameter values and the log-likelihood against the number of generations. Stationarity was assumed when the standard deviation of the split frequencies was $<0.01$ and the Gelman \& Rubin's [92] convergence diagnostic (i.e., the potential scale reduction factor) was close to 1.0. The first 1000 trees of each Bayesian run were discarded as burnin, and the remaining trees in each analysis were used to calculate the posterior probabilities and 50\% majority rule consensus tree. Bayes factors (BFs) were used to compare the models and choose the parameters that best fit the cpDNA data set [93]. BFs were calculated as the difference of the natural logarithm of the harmonic mean of the likelihood of the first model over the second model, multiplied by two [94]. BFs with positive values greater than ten were considered to provide very strong evidence against the alternative hypothesis. The best model combinations over all the six combinations tested was GTR + I for $n d h F-r p l 32 R$ and HKY $+\Gamma$ for trnD-trnT (Additional file 1: Table S4).

The topologies inferred from analyses of the cpDNA and nrDNA matrices were not identical. Several methods have been devised to estimate whether incongruence between trees is significant or not [95,96]. However, such tests could not be applied to our case, because they require the same number of terminals in both trees. Therefore, we performed a qualitative assessment of topological conflicts between the cpDNA and nrDNA trees by comparing posterior probabilities and bootstrap support values in both phylogenies (see also AMOVA test below).

\section{Additional analyses of cloned nrDNA sequences}

A matrix including a total of 147 cloned nrDNA sequences was used to analyze the partitioning of infra-individual variation among nuclear ribotypes in $P$. marginata, $P$. latifolia, and $P$. allionii. A polymorphic site in one accession was identified as additive when different nucleotides at the site were also found at the same site in at least one other accession in the data set [97]. If the polymorphism was found in one clone only, that site was not considered as additive, because it could be the product of Taq Polymerase misincorporation.

The structure of variation in the matrix of cloned nrDNA sequences was analyzed by Principal Coordinate Analysis (PCoA). We first calculated the pairwise distances in PAUP 4.0b10 [85] using the Kimura-2Parameter (K2P) substitution model, then we calculated the axes values with the software SYN-TAX 2000 [98]. We drew the three-dimensional graphic using Statistica 8.0 [99].

The possible occurrence of recombinant sequences among the nrDNA clones was determined using the program RDP3 [100], which detects the most likely recombinants and their parental sequences, as well as the recombination breakpoints in the sequences. We compared the results of all seven methods implemented in the package (e.g., RDP [100], GENECONV [101], BOOTSCANNING [102], CHIMAERA [103], MAXCHI [104], SISCANN [105], 3SEQ [106]). Common settings for all methods were to consider sequences as linear, to require phylogenetic evidence, to disentangle overlapping signals, to polish breakpoints and to check alignment consistency. Statistical significance was set at the $\mathrm{P}=0.05$ level. Default options were used in each package, except same cases reported in Additional file 1: Table S6.

We performed an analysis of molecular variance (AMOVA) based on the K2P model of nucleotide substitution and 1000 iterations (Arlequin 3.11, [107]), to test whether ITS variation was partitioned among groups that corresponded to the following hypotheses: H1) the $P$. marginata/P. latifolia and $P$. allionii clades strongly supported by the cpDNA phylogeny; H2) current taxonomical classification ( $P$. marginata, $P$. latifolia and $P$. allionii); H3) taxonomical classification with the subdivision of $P$. marginata in two cytotypes ( $P$. marginata dodecaploids, $P$. marginata hexaploids, $P$. latifolia and P. allionii).

In order to discriminate between the potential autopolyploid vs. allopolyploid origin of dodecaplois in $P$. marginata, the nucleotide diversity [108] of cloned ITS sequences from $6 x$ and $12 x$ individuals were compared using Arlequin 3.11 [106]. According to Dobeš et al. [68], a nucleotide diversity approximately twice as high in polyploids indicates the involvement of distinct genetic lineages. To check for potential correlations between nucleotide diversity and number of clones per individual or the estimated number of individuals per population, we performed Kendal Tau correlation tests using Statistica 8.0 [99]. 


\section{Additional file}

Additional file 1: Table S1. Sectional affiliations, species names, codes, and ploidy levels of species of sect. Auricula included in cpDNA phylogeny. Table S2. Species names, localities, codes and gene bank numbers of accessions of Primula sect. Auricula included in cpDNA phylogeny. Table S3. Species names, codes and GenBank/EBI accession numbers of Primula allionii, P. latifolia and P. marginata ITS clones included in nrDNA phylogeny. Table S4. Models of evolution, Base frequencies, and rates of substitutions estimated with MrModeltest for the different partitions used in this study. Table S5. Bayes factors across alternative models for two cpDNA data partitions. Table S6. Recombination analysis inferred among the nrDNA clones using the program RDP3. Figure S1. Maximum Parsimony 50\% majority-rule consensus tree inferred from cpDNA sequences of Primula sect. Auricula accessions. Figure S2. Maximum Parsimony 50\% majority-rule consensus tree of ITS clones.

\section{Competing interests}

The authors declare that they have no competing interests.

\section{Authors' contributions}

GC, EC and LM conceived the study. LG performed all lab work and analyses. GC, EC and LG provided crucial samples and contributed to data interpretation. GC, EC and LM wrote the paper. All authors read and approved the final manuscript.

\section{Acknowledgments}

The authors thank Barbara Keller for technical support, the Swiss Federal Commission for Scholarships for Foreign Students for financial support of LG, and the Institute of Systematic Botany of the University of Zurich for financial and infrastructural support.

\section{Author details}

${ }^{1}$ DISTAV, University of Genova, Corso Dogali 1M, I-16136 Genova, Italy. ${ }^{2}$ Institut für Systematische Botanik, Universität Zürich, Zollikerstrasse 107, CH8008 Zürich, Switzerland.

Received: 26 December 2011 Accepted: 11 April 2012 Published: 24 April 2012

\section{References}

1. Jiao Y, Wickett NJ, Ayyampalayam S, Chanderbali AS, Landherr L, Ralph PE, Tomsho LP, Hu Y, Liang H, Soltis PS, Soltis DE, Clifton SW, Schlarbaum SE, Schuster SC, Ma H, Leebens-Mack J, de Pamphilis W: Ancestral polyploidy in seed plants and angiosperms. Nature 2011, 473:97-100.

2. Parisod C, Holderegger R, Brochmann C: Evolutionary consequences of autopolyploidy. New Phytol 2010, 186:5-17.

3. Fawcett JA, Van de Peer Y: Angiosperm polyploids and their road to evolutionary success. Trends Evol Biol 2010, 1:e3.

4. Soltis DE, Albert VA, Leebens-Mack J, Bell CD, Paterson A, Zheng C, Sankoff D, Kerr Wall P, Soltis PS: Polyploidy and angiosperm diversification. Amer J Bot 2009, 96:336-348.

5. Balao F, Herrera J, Talavera S: Phenotypic consequences of polyploidy and genome size at the microevolutionary scale: a multivariate morphological approach. New Phytol 2011, 192:256-65.

6. Mayrose I, Zhan SH, Rothfels CJ, Magnuson-Ford K, Barker MS, Rieseberg LH, Otto SP: Recently-formed polyploid plants diversify at lower rates. Science 2011, 333:1257.

7. Soltis DE, Soltis PS, Tate JA: Advances in the study of polyploidy since Plant speciation. New Phytol 2003, 161:173-191.

8. Wood TE, Takebayashi N, Barker MS, Mayrose I, Greenspoon PB, Rieseberg LH: The frequency of polyploid speciation in vascular plants. Proc Natl Acad Sci USA 2009, 106:13875-13879.

9. Ramsey J, Schemske DW: Pathways, mechanisms, and rates of polyploid formation in flowering plants. Annu Rev Ecol Evol Syst 1998, 29:467-501.

10. Soltis PS, Soltis DE: The role of hybridization in plant speciation. Annu Rev Plant Biol 2009, 60:561-588.

11. Soltis DE, Soltis PS, Ness BD: Chloroplast-DNA variation and multiple origins of autopolyploidy in Heuchera micrantha (Saxifragaceae). Evolution 1989, 43:650-656.
12. Segraves KA, Thompson JN, Soltis PS, Soltis DE: Multiple origins of polyploidy and the geographic structure of Heuchera grossulariifolia. Molec Ecol 1999, 8:253-262.

13. Levin DA: Polyploidy and novelty in flowering plants. Amer Natural 1983, 122:1-25.

14. Mallet J: Hybrid speciation. Nature 2007, 446:279-283.

15. Paun O, Bateman RM, Fay MF, Hedrén M, Civeyrel L, Chase MW: Stable epigenetic effects impact adaptation in allopolyploid orchids (Dactylorhiza: Orchidaceae). Molec Biol Evol 2010, 27:2465-2473.

16. Paun O, Bateman RM, Fay MF, Luna JA, Moat J, Hedrén M, Chase MW: Altered gene expression and ecological divergence in sibling allopolyploids of Dactylorhiza (Orchidaceae). BMC Evol Biol 2011, 11:113.

17. Stebbins GL: Polyploidy and the distribution of the Arctic-Alpine flora: new evidence and a new approach. Bot Helv 1984, 94:1-13.

18. Stebbins GL: Polyploidy, hybridization, and the invasion of new habitats. Ann Missouri Bot Gard 1985, 72:824-832.

19. Brochmann C, Brysting AK, Alsos IG, Borgen L, Grundt HH, Scheen A-C, Even R: Polyploidy in arctic plants. Biol J Linn Soc 2004, 82:521-536.

20. Parisod C, Besnard G: Glacial in situ survival in the Western Alps and polytopic autopolyploidy in Biscutella laevigata L. (Brassicaceae). Molec Ecol 2007, 16:2755-2767.

21. Guo Y-P, Saukel J, Ehrendorfer F: AFLP trees versus scatterplots: evolution and phylogeography of the polyploid complex Achillea millefolium agg. (Asteraceae). Taxon 2008, 57:153-169.

22. Burnier J, Buerki S, Arrigo N, Küpfer P, Álvarez N: Genetic structure and evolution of alpine polyploid complexes: ranunculus kuepferi (Ranunculaceae) as a case study. Molec Ecol 2009, 18:3730-3744.

23. Guggisberg A, Mansion G, Conti E: Disentangling reticulate evolution in an arctic-alpine polyploid complex. Syst Biol 2009, 58:55-73.

24. Schmickl R, Jørgensen MH, Brysting AK, Koch MA: The evolutionary history of the Arabidopsis lyrata complex: a hybrid in the amphi-Beringian area closes a large distribution gap and builds up a genetic barrier. BMC Evo Biol 2010, 10:98.

25. Richards AJ: Primula. Portland, OR: Timber Press; 2003

26. Conti E, Suring E, Boyd D, Jorgensen J, Grant J, Kelso S: Phylogenetic relationships and character evolution in Primula L.: the usefulness of ITS sequence data. Pl Biosyst 2000, 134:385-392.

27. Guggisberg A, Mansion G, Kelso S, Conti E: Evolution of biogeographical patterns, ploidy levels and breeding systems in a diploid-polyploid species complex of Primula. New Phytol 2006, 171:617-632.

28. Guggisberg A, Baroux C, Grossniklaus U, Conti E: Genomic origin and organization of the allopolyploid Primula egaliksensis investigated by in situ hybridization. Ann Bot 2008, 101:919-927

29. Zhang L-B, Comes HP, Kadereit JW: The temporal course of quaternary diversification in the european high mountain endemic Primula sect. Auricula (Primulaceae). Int J PI Sci 2004, 165:191-207.

30. Kadereit JW, Goldner H, Holstein N, Schorr G, Zhang L-B: The stability of Quaternary speciation: a case study in Primula sect. Auricula. Alp Bot 2011, 121:23-35.

31. Kress A: Primulaceen-Studien, 10: Chromosomenzahlungen an verschiedenen Primulaceen. Teil. C: Primula, Sectio Auricula. München: Gröbenzell; 1989.

32. Abou-El-Enain MM: Chromosomal variability in the genus Primula (Primulaceae). Bot J Linn Soc 2006, 150:211-219.

33. Favarger CL: Notes de caryologie alpine IV. Bull Soc Neuchâtel Sc Nat 1965, 92:5-60.

34. Kress A: Zur verbreitung der diploiden un der tetraploiden Primula marginata Curtis. Österr Bot Z 1969, 117:14-20.

35. Bonafede F: Segnalazioni Floristiche Italiane. 673-676. Inform Bot Ital 1992, 24:50-52.

36. Bernardello R, Martini E: Segnalazioni Floristiche Italiane. 736-738. Inform Bot Ital 1993, 25:58-59.

37. Abbott RJ, Brochmann C: History and evolution of the arctic flora: In the footsteps of Eric Hultén. Molec Ecol 2003, 12:299-313.

38. Dixon CJ, Schönswetter P, Suda J, Wiedermann MM, Schneeweiss GM: Reciprocal Pleistocene origin and postglacial range formation of an allopolyploid and its sympatric ancestors (Androsace adfinis group, Primulaceae). Molec Phylogen Evol 2009, 50:74-83.

39. Eidesen PB, Alsos IG, Popp M, Stensrud Ø, Suda J, Brochmann J: Nuclear vs. plastid data: complex Pleistocene history of a circumpolar key species. Molec Ecol 2007, 16:3902-3925. 
40. Garcia S, McArthur ED, Pellicer J, Sanderson SC, Valles J, Garnatje T: A molecular phylogenetic approach to western North America endemic Artemisia and allies: untangling the sagebrushes. Amer J Bot 2011, 98:638-653.

41. Volkova PA, Travnicek P, Brochmann C: Evolutionary dynamics across discontinuous freshwater systems: rapid expansions and repeated allopolyploid origins in the Palearctic white water-lilies (Nymphaea). Taxon 2010, 59:483-494.

42. Levin DA: Minority cytotype exclusion in local plant populations. Taxon 1975, 24:35-43.

43. Štepánková J: Non-adaptive hypothesis of allopatric cytotype distribution in Myosotis lamottiana (Boraginaceae). Folia Geobot 2001, 36:147-161.

44. Baack EJ: Ecological factors influencing tetraploid establishment in snow buttercups (Ranunculus adoneus, Ranunculaceae): minority cytotype exclusion and barriers to triploid formation. Amer J Bot 2005, 92:1827-1835

45. McKinnon GE, Vaillancourt RE, Steane DA, Potts BM: An AFLP marker approach to lower-level systematics in Eucalyptus (Myrtaceae). Amer J Bot 2008, 95:368-80.

46. Fehrer J, Krak K, Chrtek JJr: Intra-individual polymorphism in diploid and apomictic polyploid hawkweeds (Hieracium, Lactuceae, Asteraceae): disentangling phylogenetic signal, reticulation, and noise. BMC Evol Biol 2009, 9:239.

47. Avise J: Molecular markers, natural history, and evolution sunderland. MA: Sinauer Associates; 2004.

48. Diadema K, Bretagnolle F, Affre L, Yuan Y-M, Médail F: Geographic structure of molecular variation of Gentiana ligustica (Gentianaceae) in the Maritime and Ligurian Alps. Taxon 2005, 54:887-894.

49. Casazza G, Zappa E, Mariotti MG, Médail F, Minuto L: Ecological and historical factors affecting distribution pattern and richness of endemic plant species: the case of the maritime and ligurian Alps hotphot. Divers Distr 2008, 14:47-58.

50. Grassi F, Minuto L, Casazza G, Labra M, Sala F: Haplotype richness in refugial areas: phylogeographical structure of Saxifraga callosa. J PI Res 2009, 122:377-387.

51. Petit C, Lesbros P, Ge X, Thompson JD: Variation in flowering phenology and selfing rate across a contact zone between diploid and tetraploid Arrhenatherum elatius (Poaceae). Heredity 1997, 79:31-40.

52. Garnier S, Alibert P, Audiot P, Prieur B, Rasplus J-Y: Isolation by distance and sharp discontinuities in gene frequencies: implications for the phylogeography of an alpine insect species, Carabus solieri. Molec Ecol 2004, 13:1883-1897.

53. SzÖvényi P, Arroyo K, Guggisberg A, Conti E: Effects of Pleistocene glaciations and life history on the genetic diversity of Saxifraga florulenta (Saxifragaceae), a rare endemic of the Maritime Alps. Taxon 2009, 58:532-543.

54. Schönswetter P, Stehlik I, Holderegger R, Tribsch A: Molecular evidence for glacial refugia of mountain plants in the European Alps. Molec Ecol 2005, 14:3547-3555

55. Brysting AK, Oxelman B, Huber KT, Moulton V, Brochmann C: Untangling complex histories of genome mergings in high polyploids. Syst Biol 2007, 56:467-476

56. Marcussen T, Oxelman B, Skog A, lakobsen KS: Evolution of plant RNA polymerase IV/N genes: evidence of subneofunctionalization of duplicated NRPD2/NRPE2-like paralogs in Viola (Violaceae). BMC Evol Biol 2007, 10:45

57. Álvarez I, Wendel JF: Ribosomal ITS sequenze and plant phylogenetic inference. Molec Phylogen Evol 2003, 29:417-434.

58. Doyle JJ: Gene trees and species trees: molecular systematics as onecharacter taxonomy. Syst Bot 1992, 17:144-163.

59. Wendel JF, Doyle JJ: Phylogenetic incongruence: window into genome history and molecular evolution. In Molecular systematics of plants II: DNA sequencing. Edited by Soltis DE, Soltis PS, Doyle JJ. Boston, MA, USA: Kluwer Academic Publishers; 1998:256-296.

60. Bailey CD, Carr TG, Harris SA, Hughes CE: Characterization of angiosperm nrDNA polymorphism, paralogy, and pseudogenes. Molec Phylogen Evol 2003, 29:435-55.

61. Linder $C R$, Rieseberg $\mathrm{LH}$ : Reconstructing patterns of reticulate evolution in plants. Amer J Bot 2004, 91:1700-1708.

62. Kimura M: The neutral theory of molecular evolution. Cambridge, UK: Cambridge University Press; 1983.
63. Birky $C W$, Fuerst $P$, Maruyama $T$ : Organelle gene diversity under migration, mutation and drift: equilibrium expectations, approach to equilibrium, effects of heteroplasmic cells, and comparison to nuclear genes. Genetics 1989, 121:613-627.

64. Palumbi SR, Cipriano F, Hare MP: Predicting nuclear gene coalescence from mitochondrial data: the three-times rule. Evolution 2001, 55:859-868.

65. Arnheim N, Krystal M, Schmickel R, Wilson G, Ryder O, Zimmer EA: Molecular evidence for genetic exchanges among ribosomal genes on nonhomologous chromosomes in man and apes. Proc Natl Acad Sci U.S.A. 1980, 77:7323-7327.

66. Hamby RK, Zimmer EA: Ribosomal RNA as a phylogenetic tool in plant systematics. In In Molecular Systematics of Plants. Edited by Soltis PS, Soltis DE, Doyle JJ. New York: Chapman and Hall; 1992:50-91.

67. Magri D, Vendramin GG, Comps B, Dupanloup I, Geburek T, Gömöry D, Latałowa M, Litt T, Paule L, Roure JM, Tantau I, van der Knaap WO, Petit RJ, de Beaulieu JL: A new scenario for the Quaternary history of European beech populations: palaeobotanical evidence and genetic consequences. New Phytol 2006, 171:199-221.

68. Dobeš C, Mitchell-Olds T, Koch MA: Intraspecific diversification in North American Boechera stricta (= Arabis drummondii), Boechera x divaricarpa, and Boechera holboellii (Brassicaceae) inferred from nuclear and chloroplast molecular markers - an integrative approach. Amer J Bot 2004, 91:2087-2101.

69. Sweigart AL, Martin NH, Willis JH: Patterns of nucleotide variation and reproductive isolation between a Mimulus allotetraploid and its progenitor species. Molec Ecol 2008, 17:2089-2100.

70. Garcia-Jacas N, Soltis PS, Font M, Soltis DE, Vilatersana R, Susanna A: The polyploid series of Centaurea toletana: glacial migrations and introgression revealed by nrDNA and cpDNA sequence analyses. Molec Phylogen Evol 2009, 52:377-394.

71. Grassi F, Labra M, Minuto L, Casazza G, Sala F: Natural hybridization in Saxifraga callosa Sm. PI Biol 2006, 8:243-252.

72. van Dijk P, Bakx-Schotman T: Chloroplast DNA phylogeography and cytotype geography in autopolyploid Plantago media. Molec Ecol 1997, 6:345-352.

73. Mast AR, Kelso S, Conti E: Are any primrose (Primula) primitively monomorphic? New Phytol 2006, 171:605-616.

74. Bennett MD, Smith JB: Nuclear DNA amounts in angiosperms. Philos Trans Ser B 1976, 274:222-274.

75. Bennett MD, Leitch IJ: Plant DNA C-values database (release 4.0, Oct. 2005) http://www.kew.org/cvalues/; 2005.

76. Otto FJ: DAPI staining of fixed cells for high-resolution flow cytometry of nuclear DNA. In Methods in Cell biology. Vol. 33rd edition. Edited by Crissman HA, Darzynkiewicz Y. New York: Academic; 1990:105-110.

77. Husband BC, Schemske DW: Cytotype distribution at a diploid-tetraploid contact zone in Chamerion (Epilobium) angustifolium (Onagraceae). Amer J Bot 1998, 85:1688-1694

78. Shaw J, Lickey EB, Beck JT, Farmer SB, Liu W, Miller J, Siripun KC, Wincer CT, Schilling EE, Small RL: The tortoise and the hare II: relative utility of 21 noncoding chloroplast DNA sequenze for phylogenetic analysis. Amer J Bot 2005, 92:142-166.

79. Shaw J, Lickey EB, Schilling EE, Small RL: Comparison of whole chloroplast genome sequence to choose noncoding regions for phylogenetic studies in angiosperms: the tortoise and the hare III. Amer J Bot 2007, 94:275-288.

80. Baum DA, Small RL, Wendel JF: Biogeography and floral evolution of Baobabs (Adansonia, Bombacaceae) as inferred from multiple data sets. Syst Biol 1998, 47:181-207.

81. Wagner A, Blackstone N, Cartwright P, Dick M, Misof B, Snow P, Wagner GP, Bartels J, Murtha M, Pendleton J: Surveys of gene families using polymerase chain-reaction - PCR selection and PCR drift. Syst Biol 1994, 43:250-261.

82. Edgar RC: MUSCLE: multiple sequence alignment with high accuracy and high throughput. Nucl Acids Res 2004, 32:1792-1797.

83. Maddison DR, Maddison WP: Mac Clade version 4: analysis of phylogeny and character evolution. Sunderland, MA, USA: Sinauer \& Associates; 2000

84. Youg ND, Healy J: GapCoder automates the use of indel characters in phylogenetic analysis. BMC Bioinf 2003, 4:6.

85. Swofford DL: PAUP*: Phylogenetic Analysis Using Parimony ( ${ }^{*}$ and other methods), Version 4b. Sunderland, MA, USA: Sinauer \& Associates; 2002. 
86. Posada D, Buckley TR: Model selection and model averaging in phylogenetics: advantages of Akaike information criterion and Bayesian approaches over likelihood ratio tests. Syst Biol 2004, 53:739-808.

87. Nylander JAA: MrModeltest v2. Program distributed by the author. Uppsala University: Evolutionary Biology Centre; 2004.

88. Lemmon AR, Moriarty EC: The importance of proper model assumption in Bayesian phylogenetics. Syst Biol 2004, 53:265-277.

89. Ronquist F, Huelsenbeck JP: MRBAYES 3: bayesian phylogenetic inference under mixed models. Bioinformatics 2003, 19:1572-1574.

90. Miller MA, Holder MT, Vos R, Midford PE, Liebowitz T, Chan L, Hoover P, Warnow T: The CIPRES Portals. CIPRES. [http//www.phylo.org/sub_sections/portal]

91. Rambaut A, Drummond AJ: Tracer 1.5.0. MCMC Trace Analysis Tool. [http://beast.bio.ed.ac.uk/Tracer]

92. Gelman $A$, Rubin DB: Inference from iterative simulation using multiple sequences. Stat Sci 1992, 7:457-511.

93. Suchard MA, Weiss RE, Sinsheimer JS: Bayesian selection of continuoustime markov chain evolutionary models. Molec Biol Evol 2001, 18:1001-1013.

94. Brown JM, Lemmon AR: The importance of data partitioning and the utility of bayes factors in Bayesian phylogenetics. Syst Biol 2007, 56:643-665.

95. Shimodaira H, Hasegawa M: Multiple comparisons of log-likelihoods with applications to phylogenetic inference. Molec Biol Evol 1999, 16:1114-1116.

96. Lee MSY, Hugall AF: Partitioned likelihood support and the evaluation of data set conflict. Syst Biol 2003, 52:15-22.

97. Fuertes Aguilar J, Nieto Feliner G: Additive polymorphisms and reticulation in an ITS phylogeny of thrifts (Armeria, Plumbaginaceae). Molec Phylogen Evol 2003, 28:430-447.

98. Podani J: SYN-TAX 2000. Computer programs for data analysis in ecology and systematics. User's manual. Budapest, Hungaria: Scientia Publishing; 2001.

99. StatSoft Inc. Statistica (data analysis software system) version 8.0 [www.statsoft.com].

100. Martin DP, Lemey P, Lott M, Moulton V, Posada D, Lefeuvre P: RDP3: a flexible and fast computer program for analyzing recombination. Bioinformatics 2010, 26:2462-2463.

101. Padidam M, Sawyer S, Fauquet CM: Possible emergence of new geminiviruses by frequent recombination. Virology 1999, 265:218-225.

102. Salminen MO, Carr JK, Burke DS, McCutchan FE: Identification of breakpoints in intergenotypic recombinants of HIV type 1 by Bootscanning. AIDS Res Hum Retroviruses 1995, 11:1423-1425.

103. Posada D, Crandall KA: Evaluation of methods for detecting recombination from DNA sequences: computer simulations. Proc Natl Acad Sci USA 2001, 98:13757-13762.

104. Maynard Smith J: Analyzing the mosaic structure of genes. J Molec Evol 1992, 23:126-129.

105. Gibbs MJ, Armstrong JS, Gibbs AJ: Sister-scanning: a Monte Carlo procedure for assessing signals in recombinant sequences. Bioinformatics 2000, 16:573-582.

106. Boni MF, Posada D, Feldman MW: An exact non-parametric method for inferring mosaic structure in sequence triplets. Genetics 2007, 176:1035-1047.

107. Excoffier L, Laval G, Schneider S: Arlequin ver. 3.0: an integrated software package for population genetics data analysis. Evol Bioinf Online 2005, $1: 47-50$.

108. Tajima F: Evolutionary relationship of DNA sequences in finite populations. Genetics 1983, 105:437-460.

\section{Submit your next manuscript to BioMed Central and take full advantage of:}

- Convenient online submission

- Thorough peer review

- No space constraints or color figure charges

- Immediate publication on acceptance

- Inclusion in PubMed, CAS, Scopus and Google Scholar

- Research which is freely available for redistribution 